\title{
THE COMPETITIVENESS OF MANUAL AND MECHANIZED CORN CULTIVATION
}

\author{
Juniska Muria Sariningpuri" ${ }^{*}$, Amzul Rifin ${ }^{* *}$, and Rokhani Hasbullah $\left.{ }^{* * *}\right)$ \\ *) PT Salim Ivomas Pratama (SIMP) \\ Jl. Jendral Sudirman Kav 76-78, Jakarta \\ ${ }^{* *}$ Department of Agribusiness, Faculty of Economics and Management, Bogor Agricultural University \\ Jl. Kamper, Wing 4 Level 5 Campus IPB Dramaga, Bogor 16680 \\ ${ }^{* * *}$ Department of Mechanical and Biosystem Engineering, Faculty of Agricultural Technology, \\ Bogor Agricultural University \\ PO BOX 220, Campus IPB Dramaga, Bogor 16602
}

\begin{abstract}
In 2015, total imports of corn in Indonesia reached 3.1 million tons due to lower corn production of Indonesia. One way to overcome this is to apply the technology mechanization in the cultivation process as practiced by the country largest corn producer in the world. The purpose of this study is to know the level of competitiveness of mechanized corn cultivation and manual. In addition, it is to determine the effect of government policy on competitiveness of both type of corn cultivation. The analytical method used is the Policy Analysis Matrix (PAM). The analysis showed that mechanized corn cultivation is competitive so that the business is feasible to be developed. It is seen from the DRC and PCR-corn agribusiness based on mechanization level values that less than one is 0.54 and 0.50. The manual corn cultivation, however, only show a competitive advantage but does not have a comparative advantage. Output policy is a policy that better influence both type mechanized and manual corn cultivation.
\end{abstract}

Keywords: competitiveness, corn, Policy Analysis Matrix (PAM)

\begin{abstract}
ABSTRAK
Pada tahun 2015, total impor jagung di Indonesia mencapai 3.1 juta ton disebabkan produksi jagung Indonesia yang rendah. Salah satu cara untuk mengatasi hal tersebut adalah dengan menerapkan teknologi mekanisasi dalam proses budidaya seperti yang dilakukan oleh negara-negara penghasil jagung terbesar di dunia. Tujuan penelitian ini mengetahui kondisi dayasaing budidaya jagung yang dilakukan secara mekanisasi dan manual. Di samping itu, untuk mengetahui pengaruh kebijakan pemerintah terhadap dayasaing budidaya jagung secara mekanisasi dan manual. Metode analisis yang digunakan adalah Policy Analysis Matrix (PAM). Hasil analisis menunjukkan Budidaya jagung secara mekanisasi memiliki dayasaing sehingga bisnis tersebut layak untuk dikembangkan. Hal ini dilihat dari nilai DRC dan PCR agribisnis jagung berbasis mekanisasi yang benilai kurang dari satu, yaitu 0.54 dan 0.50. Berbeda halnya dengan budidaya jagung secara mekanisasi, budidaya jagung secara manual diketahui hanya memiliki keunggulan kompetitif namun tidak memiliki keunggulan komparatif. Kebijakan output merupakan kebijakan yang paling berpengaruh baik untuk budidaya jagung secara mekanisasi maupun manual.
\end{abstract}

Kata kunci: dayasaing, jagung, Policy Analysis Matrix (PAM)

\footnotetext{
${ }^{1}$ Corresponding author:

Email: juniska.muria@gmail.com
} 


\section{INTRODUCTION}

Corn is one of the major commodity crops as a source of carbohydrates and it is the second after rice that was instrumental in the trade of agricultural products both nationally and internationally. In addition as a material consumption, corn is also very instrumental in the feed and food industries that require the biggest supply than for immediate consumption. Domestic corn demand for animal feed is estimated at more than $55 \%$ of the total national production, while food consumption is only about $30 \%$, and the remainder to other industrial needs and seeds (MOA, 2007). Corn demand especially for industrial and animal feed continues to increase every year. The rate of increase in demand for corn for the food industry is increased by $3 \%$ per year, while for animal feed increased by $5.78 \%$ per year (Ministry of Agriculture, 2015). Government took a corn imports to cover the needs of the ever-increasing demand. The rate of increase in imports of corn in the years 20112015 has reached $15.56 \%$ per year (BPS, 2016). The root cause of unmet demand in the country is for the national corn productivity which is still low while the demand is huge. Low productivity due to the present corn cultivation is still done manually by using human power in all farming activities. It is of course very different from the corn-producing countries in the world that have implemented mechanization technology in the production process. Mechanization technology is the introduction and development of agriculture by using engine technology in all forms to increase production capacity (Azogu, 2009). Mada (2013) and Dixit et al. (2014) states that mechanization technology can reduce labor costs, increase production and improve work efficiency. Some problems in implementing technology mechanization are low output prices, a huge investment, lack of land ownership, and the lack of policies in agricultural production (Taiwo and Kumi, 2015).

One of the businesses that began implementing mechanization technology in the cultivation of corn is PT XYZ. PT XYZ is a company engaged in agriculture which looks at corn as a business opportunity that has the advantage to be developed. In the development of the corn business, PT XYZ using the machine in all farming activities ranging from land preparation to harvest. Farming activities by PT XYZ included in the high mechanization. According to Marie et al. (2011), mechanization is divided into four levels: 1) Mechanization lower is aquaculture activities entirely done by humans or assistance animal, 2)
Medium mechanization is a farming activities using a combination of agricultural machinery with human labor, 3) High mechanization is where all aquaculture activities carried out with the use of agricultural machinery which is operated by human beings, 4) full mechanization is all aquaculture activities carried out with the use of agricultural machinery with the help of software or robots.

An innovation made by PT XYZ is a new thing in the cultivation of corn in Indonesia because until now there are still no business operators who apply the full mechanization in the cultivation process of corn. Capital and large investment are constraint for businesses to conduct such kind of business while until the selling price corn is still unstable in Indonesia. Therefore it is necessary for competitiveness analysis to determine the condition of the competitiveness and viability corn farming business with mechanization technology. XYZ competitiveness needs to be compared with the competitiveness of corn cultivation manually as practiced by farmers. This is because $90 \%$ of corn cultivation in Indonesia is still done manually by the farmer. According to Tambunan (2013), competitiveness is the ability of a business to be able to improve its position in the same market.

One method of analysis of competitiveness is Policy Analysis Matrix (PAM). PAM is an effective analytical tool to see the impact of government policy and market distortions of the competitiveness of the commodity from the cultivation, processing and marketing (Monke and Pearson, 1989). PAM can be known through the analysis of comparative and competitive advantages of a farm. It is where a comparative advantage in PAM demonstrated by Domestic Cost Ratio (DRC) and while the competitive advantage represented by Private Cost Ratio (PCR). Determination of the DRC and PCR in the PAM cannot be separated from the agricultural policies adopted by governments. Some agricultural policies implemented by the government of Indonesia is the Minister of Agriculture of the Republic of Indonesia Number 57/PERMENTAN/Pk.110/11/2015 on the Entry and Feed Ingredients Plant Origin To and from the territory of the Republic of Indonesia, Ministry of Finance of the Republic of Indonesia Number 224/ PMK .04/2015 which regulates the number of quota of imported goods entering into the State of Indonesia and the Minister of Agriculture of the Republic of Indonesia number 60/Permentan/SR.310/2015 on the Distribution and Use of Subsidized Fertilizer, 2016. 
Objectives to be achieved through this research were to determine the conditions of competitiveness of corn cultivation that is done in mechanization and manually and determine the effect of government policy on competitiveness of corn cultivation in mechanization and manually.

\section{METHODS}

This research was conducted in two locations to compare the competitiveness of agribusiness corn in mechanization and manually. Location of the study was observed in the process of agribusiness corn mechanization is one of the cornfields owned by PT. $\mathrm{XYZ}$ in the village of BatuPutih, District Talisayan, Berau district, East Kalimantan. Land that has been planted with corn is 200 ha. While the study site for the observation of corn agribusiness manually performed in Demak, Central Java. Selection of the Demak regency as sampling sites manually corn cultivation due Demak has characteristics similar to the land field sites in Berau, besides this district also has a harvest period equal to Berau. The study was conducted in January 2016 to May 2016.

The data used in this study are primary data and secondary data. Primary data is used to analyze the competitiveness of the cultivation of corn manually performed by farmers in Demak, Central Java. This data is obtained by dividing the questionnaire and in-depth interviews with farmers in Demak, Central Java. While the secondary data is used to analyze the competitiveness of the cultivation of corn mechanization obtained from production budget and cash flow during the second cropping production in 2015 that is in November 2015 and February 2016. Some of the steps being taken in analyzing the competitiveness of corn cultivation with PAM method are as follows: 1) Identifying the complete input allocation of corn-based farming of mechanization and manual. 2) Determining the shadow prices of the input and output corn-based agribusiness of mechanization and manual. 3) Choosing the tradable costs that cost prevailing in the world market and domestic costs that are costs that apply to the domestic market. 4) Calculating based acceptance of cultivation of corn mechanization and manual. 5) Calculating and analyzing a wide range of indicators produced by PAM.

\section{The determination of shadow price}

The shadow price is the price occurs in perfect competition and equilibrium (Monke and Pearson, 1989). Acquisition of shadow price in the market is done with the adjustment to the prevailing market price. Some of the prices required in determining the shadow price of which is the price of Free On Board (FOB) that the prices used to determine the price of commodities that had been exported and the price of Cost Insurance Freight (CIF) is the price used to determine the price of the commodity prices are usually imported. These prices will be recalculated with the influence of subsidies, taxes, minimum wage and others.

\section{Price Shadow Output}

Shadow price of output to be used is output prices prevailing on the free market. If the output is used export commodities, the commodity price will be determined based on the FOB price. Whereas if the output used is imported commodities, the price used is the price CIF. Pipil dried corn prices as commodity investigated using CIF prices, because until now corn is a commodity imported. CIF prices for corn dry pipil obtained by dividing the number of imported corn dry pipil for one year at a total cost of its imports are then multiplied by the value of the rupiah during 2015 . So the shadow price obtained for pipil dried corn output is $\mathrm{Rp} 2,860$ per $\mathrm{kg}$.

$$
\mathrm{CIF}=\left(\mathrm{M}_{\mathrm{t}} \times \mathrm{OER}\right)+\text { Transport Cost }
$$

\section{Description:}

CIF : Cost Insurance Freight

$\mathrm{M}_{\mathrm{t}}$ : Value of Indonesian imports in year $\mathrm{t}$ (USD)

OER : the rupiah exchange rate

Price Shadow Input (Production Facility)

Inputs used in corn-based agribusiness mechanization are divided into two production facilities and farm tools. Production inputs include seeds, fertilizers NPK, Urea fertilizer, and pesticides. Farm tools are in the form of farm machines.

Seeds that are used as one of the inputs of production facilities using hybrid seeds are imported, so as to determine the shadow price of seeds using CIF price limit is multiplied by the cost of transport and the exchange 
rate. So the shadow price for maize seed is $\mathrm{Rp} 38,142$ per $\mathrm{kg}$. The shadow price of NPK and urea using CIF price limit multiplied by SER its last plus transport costs. Shadow prices for NPK and urea respectively is Rp5,794 and Rp4,244 per kg. Price pesticides used in this study were taken from the price prevailing at the sites. This is due to the drug trade that has been left to the market, so there are no subsidies for pesticides while the price on the international level as well not exists.

$$
\mathrm{FOB}=\left(\mathrm{X}_{\mathrm{t}} \mathrm{x} \text { OER }\right)+\text { Transport Cost }
$$

Description:

FOB $:$ Free On Board
$\mathrm{X}_{\mathrm{t}}: \begin{aligned} & \text { Value of Indonesian exports in year } \mathrm{t} \\ & \text { (USD) }\end{aligned}$
OER : the rupiah exchange rate

Other inputs used in corn-based agribusiness mechanization are agricultural machinery used in the production process. Agricultural machinery used consists of a tractor, planter, fertilizing machines, spray machines and harvesting machinery. The whole machine used is an imported commodity, so the limit price used is the price CIF limit multiplied by the exchange rate and cost of transportation.

The shadow price of labor

Labor costs for each region is determined based on the minimum wage applicable at the time of the study. The pricing of labor shadow price that is used is private prices are reduced by the unemployment rate in each region. The shadow price of labor prevailing in Berau is USD94,905 per day while for Demak its labor shadow price is USD39,979 per day.

\section{Price Shadow Values Currencies}

Shadow price value of the exchange rate is the price of domestic currency in relation to foreign currencies which occurred at the market exchange rate at competitive of perfect conditions. One approach to calculate the price of the shadow exchange rate is the shadow price should be at a level equilibrium exchange rate. Balance occurs when the hedged all money market and subsidies to exports and imports eliminated. Equilibrium exchange rate can be approximated premises using Standard Conversion Factor (SCF) as a correction factor to the official exchange rate applicable. SER value calculation results in 2015 amounted to USD13,625.

$$
S E R_{t}=\frac{O E R_{t}}{S C F_{t}}, S C F_{t}=\frac{X_{t}+M_{t}}{\left(X_{t}+T X_{t}\right)+\left(M_{t}+T M_{t}\right)}
$$

Description:

$\mathrm{SER}_{\mathrm{t}}$ : nilai tukar bayangan tahun $\mathrm{t}(\mathrm{Rp} / \mathrm{US} \$)$

$\mathrm{SCF}_{\mathrm{t}}$ : stadar convertion factor (faktor konversi standar) tahun $\mathrm{t}$

$\mathrm{X}_{\mathrm{t}}$ : Value of Indonesian exports in year $\mathrm{t}$ (USD)

$M_{t}$ : Value of Indonesian imports in year $t$ (USD)

$\mathrm{TX}_{\mathrm{t}}$ : The export tax in year $\mathrm{t}$ (USD)

$\mathrm{TM}_{t} \quad$ : The import duties and import duties in year t (USD)

\section{Allocation of Cost Components of Domestic and Foreign (Tradable)}

The allocation of domestic costs are costs that cannot be traded on the international market, while foreign cost is the cost of inputs that are traded in the international market (Monke, 1989). Domestic and foreign costs of inputs used in corn-based agribusiness mechanization and manual input output seen from the table obtained from BPS 2010. Input was obtained and then classified by sector in the table of input and output. Domestic and foreign cost allocation for the cultivation of corn mechanization is shown in Table 1.

Table 1. Domestic and Foreign Cost Allocation of PT $\mathrm{XYZ}$

\begin{tabular}{lcc}
\hline \multicolumn{1}{c}{ Input type } & $\begin{array}{c}\text { Domestic } \\
(\%)\end{array}$ & $\begin{array}{c}\text { Foreign } \\
(\%)\end{array}$ \\
\hline Corn & 84 & 16 \\
Other items of wood, cork, bamboo & 96 & 4 \\
and rattan & 18 & 82 \\
Fertilizer & 0 & 100 \\
Pesticide & 1 & 100 \\
Other metal items & 70 & 30 \\
Batteries and accumulators & 72 & 28 \\
Motor vehicles except motorcycles & 99 & 1 \\
Residential buildings and non- & & \\
residential & 99 & 1 \\
agricultural infrastructure & 73 & 27 \\
Goods from plastic & & \\
\hline
\end{tabular}

Source: Input costs of production XYZ (2015) and BPS (2010) 
Allocation of cost of production by foreign and domestic components for the cultivation of corn manually also refers to the input-output tables BPS 2010. The cost allocation to domestic and foreign corn cultivation manually is shown in Table 2 .

Tabel 2. Cost Allocation of Domestic and Foreign Farmers

\begin{tabular}{lcc}
\hline \multicolumn{1}{c}{ input Type } & $\begin{array}{c}\text { Domestic } \\
(\%)\end{array}$ & $\begin{array}{c}\text { Foreign } \\
(\%)\end{array}$ \\
\hline Corn & 84 & 16 \\
Goods of oil and gas refineries & 23 & 76 \\
Fertilizer & 18 & 82 \\
Pesticide & 0 & 100 \\
Goods from plastic & 73 & 27 \\
agricultural infrastructure & 99 & 1 \\
\hline
\end{tabular}

Source: Input costs of production XYZ (2015) and BPS (2010)

\section{Analysis of Competitiveness}

The results of the analysis of competitiveness by the PAM method are shown in Table Matrix PAM. In the PAM matrix, will be obtained private price that is the price actually paid by businesses and the social prevailing prices on the world market. Private prices issued by the business is the price that has been affected by the implementation of policies such as subsidies and tax policies, while the social price is the price that comes from the manufacturer before it is affected by the implementation of the policy. Comparative and competitive advantages demonstrate the competitiveness of farming. Comparative advantage in PAM is indicated by the DCR, while the competitive advantage represented by the value PCR. Table 3 is explaining the results of the analysis of competitiveness through PAM method.

Tabel 3. Policy Analysis Matrix (PAM)

\begin{tabular}{lcccc}
\hline & & \multicolumn{2}{c}{ Price } & \\
\cline { 3 - 4 } Information & Income & $\begin{array}{c}\text { Input } \\
\text { treadable }\end{array}$ & $\begin{array}{c}\text { Input } \\
\text { Non } \\
\text { treadable }\end{array}$ & Profit \\
\hline Private Price & $\mathrm{A}$ & $\mathrm{B}$ & $\mathrm{C}$ & $\mathrm{D}$ \\
Social price & $\mathrm{E}$ & $\mathrm{F}$ & $\mathrm{G}$ & $\mathrm{H}$ \\
Divergence & $\mathrm{I}$ & $\mathrm{J}$ & $\mathrm{K}$ & $\mathrm{L}$ \\
\hline
\end{tabular}

Where:

Private Cost Ratio $(\mathrm{PCR})=\mathrm{C} /(\mathrm{A}-\mathrm{B})$

Domestic Resource Cost Ratio (DRC) $=\mathrm{G} /(\mathrm{E}-\mathrm{F})$

\section{Comparative and Competitive Advantage Analysis}

Private Cost Ratio (PCR)

PCR value is the value used to determine how much the amount of output can be issued to pay for the entire cost of inputs that have been used and remain under competitive conditions. If a farm is able to minimize the PCR value, then the farm will get the maximum benefit. The maximum benefit is obtained by minimizing the cost of domestic factors. If the value of PCR $<1$ then it can be said that the farm has a competitive advantage because it has the ability to finance domestic factors in private and these capabilities can be increased (Kurniawan, 2008).

\section{Domestic Cost Ratio (DCR)}

The ability of a farm to finance domestic factors on the price of reflection can be seen from the DCR owned by the farm. If the value obtained DCR $>1$ then we can say farming is judged not to be able to survive without government intervention, so it would be better if import than producing their own. Contrary if the DCR $<1$ then we can say farm production system is more efficient and have competitiveness in the international market so rated commodity that has a chance to be exported (Kurniawan, 2008). This research is expected to provide information on the corn-based agribusiness mechanization technology to the public and can also provide recommendations for companies to continuously improve competitiveness owned.

The framework that will be performed in this study is using the Policy Analysis Matrix (PAM). The framework in this study is illustrated by Figure 1.

\section{RESULTS}

\section{Competitiveness of Corn Cultivation Mechanized Vs. Manual}

Competitiveness of a farm is shown through comparative and competitive advantages of the farming business. The results of the analysis of competitiveness cultivation of corn mechanization and manually using the PAM. Table 4 shows that social benefits $\mathrm{XYZ}$ is Rp5,784,781 per hectare, which means XYZ indicated to have a comparative advantage. Mantau et al. (2013) 
states that a farm has a comparative advantage, it happens when the indication of social benefit value is positive. Falatehan and Wibowo (2008) explains that a farm that has a social advantage is positive, it can be said that economic farming activities can continue as it generates profits. Whereas social benefits to farmers in Demak is negative so that farming are indicated to have a comparative advantage. This is due to farmers' limited capital, so that in the absence of government policy in the form of subsidizing fertilizer and seed growers can not have a comparative advantage. Comparative and competitive advantages between corn cultivation in mechanized and manual is shown in Figure 2

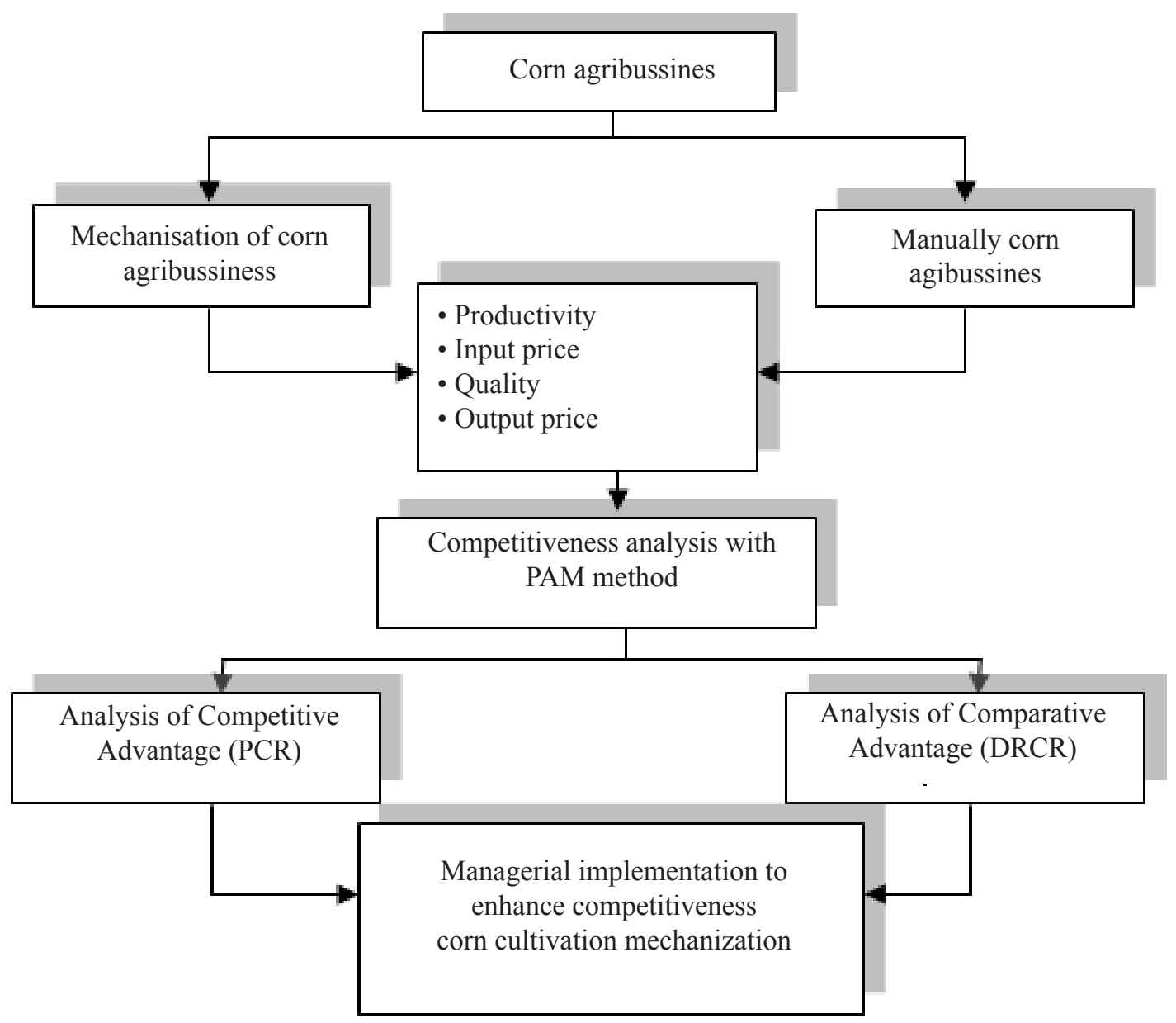

Figure 1. Research framework

Table 4. PAM tabulation of corn cultivation in mechanization and manual (in million IDR)

\begin{tabular}{|c|c|c|c|c|c|c|c|c|}
\hline \multirow[t]{3}{*}{ Information } & \multirow{2}{*}{\multicolumn{2}{|c|}{ Income }} & \multicolumn{4}{|c|}{ Price } & \multirow{2}{*}{\multicolumn{2}{|c|}{ Profit }} \\
\hline & & & \multicolumn{2}{|c|}{ Input treadable } & \multicolumn{2}{|c|}{ Input Non treadable } & & \\
\hline & $\begin{array}{c}\text { Mechaniza- } \\
\text { tion }\end{array}$ & Manually & $\begin{array}{c}\text { Mechaniza- } \\
\text { tion }\end{array}$ & Manually & $\begin{array}{c}\text { Mechaniza- } \\
\text { tion }\end{array}$ & Manually & $\begin{array}{c}\text { Mechaniza- } \\
\text { tion }\end{array}$ & Manually \\
\hline Private Price & 20.4 & 12.1 & 4.8 & 1.8 & 7.7 & 7.6 & 7.9 & 2.7 \\
\hline Social price & 17.2 & 10.8 & 4.4 & 2.8 & 6.9 & 8.2 & 5.8 & $(0.2)$ \\
\hline Divergence & 3.2 & 1.3 & 0.3 & $(0.1)$ & 0.8 & $(0.6)$ & 2.1 & 2.9 \\
\hline
\end{tabular}


DRC owned mechanized cultivation worth $<1$ that is equal to 0.54 so that it can be said that the farm has a comparative capabilities. Corn mechanization of farming has a comparative advantage because at social prices produce one unit of added value of 0.54 units. This shows that the cultivation of corn mechanization can survive and develop without the intervention of government policy. Beside having a comparative advantage, the farm also has a competitive advantage because it has a value of PCR $<1$ that is equal to 0.50 . It is not much different from the research that has been done before concluding that corn farming in Sumbawa has a competitive advantage and comparative value and PCR DRC $=0.39=0.25$ (Nurwahidah et al. 2015). The smaller the value of DRC a farm then the farm has a comparative advantage are higher. Farming has a comparative advantage shows that farming has been efficient when seen utilization of domestic resources available if it is produced domestically (Maharani et al. 2014).

In contrast to what happened in the cultivation of corn mechanization, cultivation of corn manually does not have a comparative advantage. It is seen from the DRC value that is more than one. In other words, the cultivation of corn manually is unable to finance their domestic factors at social prices without any intervention from the government. This is due to limited capital owned by farmers, so they tend not be able to finance the cost of production in the absence of government policy in the form of subsidies for fertilizer and seed. However, although it has no comparative advantage, manually corn cultivation has shown a competitive advantage with the PCR value of 0.738 . This means that to produce one unit of the necessary domestic factor costs amounted to 0.738 units.

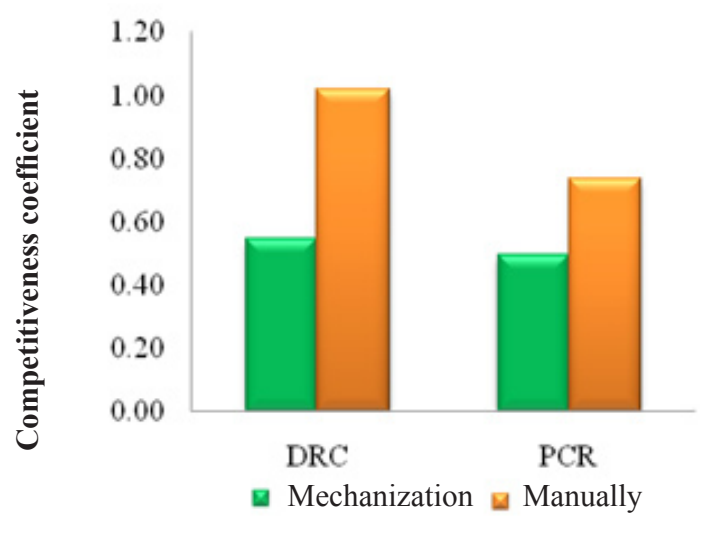

Competitiveness indicator

Figure 2. Indicators of comparative and competitive advantage
Manual corn cultivation can have comparative and competitive advantages, if there is need for government intervention in the form of agricultural policies adopted by governments. The policies are applied, among others, import policy, subsidy policy, and financial policy. The policies that have been implemented by the government proved to be a positive influence on the cultivation of corn manually. This is evidenced by the provision of subsidies in the form of seed and fertilizer subsidies to farmers, thus removing the input costs below the cost should be. With this input cost reduction, the income of farmers will increase. The increase in revenues is of course to be followed by increased profits, so we can say the implementation the policy can improve the competitiveness of the manual corn cultivation.

\section{Effect of Government Policy Towards Competitiveness in Corn Cultivation}

The government's policy on corn imports set out in the regulations the Minister of Trade No. 20 / M-DAG / PER / 3/2016 on corn imports that only allows the State Logistics Agency (Bulog) as a corn importer in Indonesia. So there is a limit to the number of importers who want to buy imported corn. Suryana (2014) also mentioned that in order to protect the falling price of corn at the farmer as a result of imports, the government imposed import corn duty of $5 \%$ according to the Minister of Finance Regulation No. 591/2004. Other regulations that affect the output of maize in Indonesia is the Minister of Agriculture of the Republic of Indonesia Number 57 / PERMENTAN / Pk.110 / 11/2015 on the Entry and Feed Ingredients Plant Origin to and from the territory of the Republic of Indonesia. Under this rule is written terms of the quality of feed ingredients of plant origin (one of which was corn) to be imported into Indonesia. Other policy related to the output corn is dry pipil Indonesian Minister of Finance Regulation No. 224 / PMK.04 / 2015 which regulates the number of quotas of goods imported into the Country Indonesia. Farmers in Indonesia also facilitated in terms of supply of fertilizers. The Indonesian Government implement the Minister of Agriculture of the Republic of Indonesia Number 60 / Permentan / SR.310 / 2015 on the use of subsidized fertilizer meant for farmers involved in the farmer groups, is not a company engaged in agriculture. According to Hermawan et al. (2011), the purpose of the fertilizer subsidy is to ensure availability of fertilizers, increased food production, increase farmers' income, and employment. 
Competitive advantage of both on the mechanized or manual corn cultivation is worth less than its comparative advantage. This is thought to be caused due to the production corn in Indonesia is lower compared to corn production in other countries. Statistical data FAOSTAT mention that the national corn production in Indonesia in 2015 was 19,387,022 tons, while the United States as the world's largest maize producer has a production of $273,820,066$ tons. World corn production in 2015 is shown in Figure 3. Competitive advantage in the cultivation of corn manually lower than a competitive advantage in the cultivation of corn mechanization $(\mathrm{XYZ}=0.459$ and farmers $=0.73)$. It is seen from lower private costs incurred by PT XYZ to produce its product than the private costs incurred by the respondent farmers to produce their products.

\section{Managerial Implication}

The results showed that corn cultivation is done by PT XYZ competitive. This owe to the application of technology to increase corn production. As written Adekola and Akinyemi (2014); Zangeneh and Banaeian (2014) and Rehman et al. (2016) that one solution is to increase corn production mechanization implementing technology in the cultivation process starting from land preparation, planting, harvesting and post-harvest. In addition to the amount of production, competitiveness that is owned by the cultivation of corn mechanization is also caused by the application output by government policy. This policy is considered to be very influential for all actors, both corn farming mechanization and manual in Indonesia. Output policy is applied in the form of corn import policy. With this policy, corn farming actors get higher revenues than in the absence of the policy.

\section{CONCLUSIONS AND RECOMMENDATIONS}

\section{Conclusions}

It can be concluded that the mechanized corn cultivation have competitive power so that the business is feasible to be developed. It is seen from the DRC and PCRbased agribusiness corn mechanization level values less than one are 0.54 and 0.50 . Unlike the case with corn cultivation is mechanized, the cultivation of corn manually shows only a competitive advantage but does not have a comparative advantage. This difference can be seen from the PCR value of 0.74 and a manual cultivation DRC rely more than one that is equal to 1.02. The figure shows the manual cultivation can only survive with the intervention of the government. In contrast, the cultivation of corn XYZ can survive and continue to be developed without any help from the government. Output policy is a policy of the most influential for corn cultivation either mechanized or manual. Under the policy, corn farmers can receive a better selling price than in the absence of the policy.

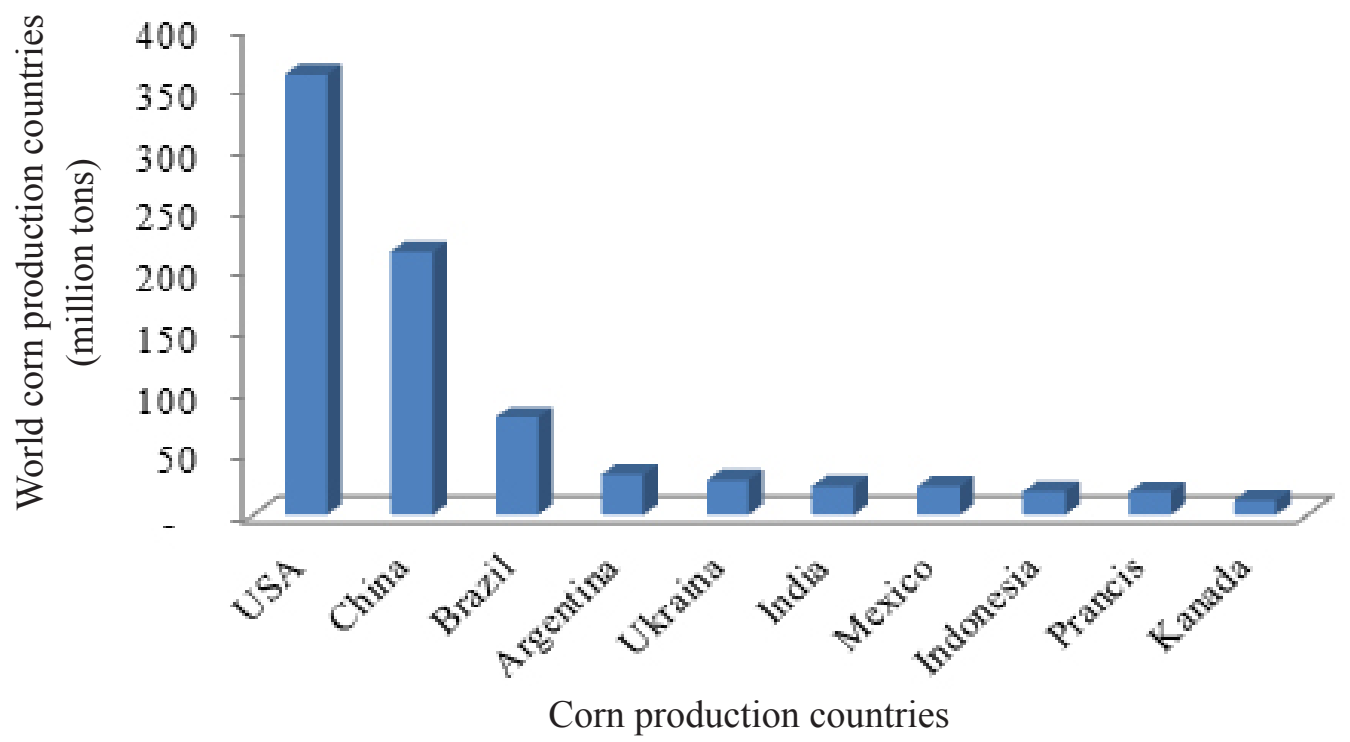

Figure 3. World corn production in 2015 


\section{Recommendations}

Several attempts may be takes to increase profits, among others: the efficient use of agricultural machinery, professional workforce efficiency, as well as improving the work of agricultural machinery in accordance with the engine capacity. Research of Hermawan (2011) says that by improving the design of the machine tool can improve the performance of agricultural planting and fertilizing corn.Meanwhile, to improve the competitiveness of corn cultivation can be done manually by improving farm management corn in farmers' groups in an integrated and efficient. As the results of Sumarno et al. (2015) which states that farmers who do Implementation of Integrated Crop Management (ICM) have higher productivity than non PTT farmer groups. Future is expected the government can pay more attention to the farm mechanization such as the provision of working capital loans, the development of agricultural research centers based mechanization, and the construction of post-harvest facilities corn such as corn dryer factory which is easily accessible for farmers (Adamade and Jackson, 2014; Syu'aib, 2016; Abdulquadri and Mohammed, 2012). The government also should encourage manufacturers of agricultural machinery locally in the procurement and use of agricultural machinery that is affordable for farmers (Setiawan et al. 2006) it has begun to be applied in the country of Nigeria (Akinbamowo, 2013). As did the Chinese state in meeting their food needs with the application of agricultural mechanization in the cultivation process (Adekola et al. 2014).

\section{REFERENCES}

Abdulquadri AF, Mohammed BT. 2012. The role of agricultural cooperatives in agricultural mechanization in Nigeria. Journal of Agricultural Science 8(5):537-539.

Adamade, Jackson. 2014. Agricultural mechanization: a strategy for food sufficiency. Journal of Agriculture Science 4(3):152-156.

Adekola KA, Akinyemi TA. 2014. Agricultural production and development in Northeast Jilin Province of China. Journal of Advances in Agricultural Science and Technology 2(9):1-6.

Adekola KA, Alabadan BA, Akinyemi TA. 2014. China Agricultural mechanization development experience for developing countries. Journal of Agriculture Innovations and Research. 3(2):655-
658.

Akinbamowo RO. 2013. A review of government policy on agricultural mechanization in Nigeria. Journal of Agriculture Extension and Rural Development 5(8):146-153.

Azogu II. 2009. Promoting appropriate mechanization technologies for improved agricultural productivity in Nigeria: the role of the national centre for agricultural mechanization. Journal of Agricalture Technology and Engineering 17(2):1-10.

[BPS] Badan Pusat Statistik. 2010. Tabel Input Output Indonesia 2010. Jakarta: Badan Pusat Statistik.

[BPS] Badan Pusat Statistik. 2016. Laju Impor Jagung Indonesia. https://www.bps.go.id/all_ newtemplate.php [25 November 2016].

Dixit J, Sharma S, Ali M. 2014. Present status, potential and future needs for mechanization of agricultural operations in Jammu and Kashmir state of India. Journal of CIGR 16(3):87-96.

Falatehan AF, Wibowo A. 2008. Analisis keunggulan komparatif dan kompetitif pengusahaan komoditi Jagung di Kabupaten Grobogan (studi kasus: Desa Panunggalan, Kecamatan Pulokulon, Kabupaten Grobogan, Jawa Tengah). Jurnal Agribisnis dan Ekonomi Pertanian 2(1):1-15.

[FAO] Food and Agriculture Organization. 2016. Agriculture Statistic. http://faostat.fao.org/ site/339/default.aspx. [22 Agustus 2016].

Hermawan DS, Daryanto A, Sanim B, Siregar H. 2011. Analisis kebijakan subsidi pupuk: penentuan pola subsidi dan sistem distribusi pupuk di Indonesia. Jurnal Manajemen \& Agribisnis 8(2):85-96.

Hermawan W. 2011.Perbaikan desain mesin penanam dan pemupuk jagung bertenaga traktor tangan. Jurnal Keteknikan Pertanian 25(1):9-18. https:// doi.org/10.19028/jtep.25.1.9-18.

[Kementan] Kementrian Pertanian. 2015. Peraturan Menteri Pertanian Republik Indonesia Nomor 57/PERMENTAN/Pk.110/11/2015tentang Pemasukan dan Pengeluaran Bahan Pakan Asal Tumbuhan Ke dan Dari Wilayah Negara Republik Indonesia. Jakarta: Kementan.

[Kemenkeu] Kementrian Keuangan. 2015. Peraturan Menteri Keuangan Republik Indonesia Nomor 224/PMK.04/2015 Jumlah Kuota Barang Impor yang Masuk ke Dalam Negara Indonesia. Jakarta: Kemenkeu.

[Kementan] Kementrian Pertanian. 2015. Peraturan Menteri Pertanian Republik Indonesia Nomor 60/Permentan/SR.310/2015 tentang Distribusi 
dan Penggunaan Pupuk Bersubsidi 2016. Jakarta: Kementan.

Kurniawan. 2008. Analisis efisiensi ekonomi dan dayasaing jagung pada lahan kering di Kabupaten Tanah Laut, Kalimantan Selatan. Forum Pascasarjana 31(2): 93-103.

Mada DA, Mahai S. 2013. The role of agricultural mechanization in the economic development for small scale farms in Adamawa State. Journal of Engineering and Science 2:91-96.

Maharani N, Koestiono D, Dwiastuti R. 2014.Analisis keunggulan komparatif komoditas jagung (Zea Mays L.) di Kabupaten Kediri. Journal of AGRISE 14(3):167-181.

Mantau Z, Bahtiar, Aryanto. 2013. Analisis Dayasaing Usahatani Jagung di Kabupaten Bolaang Mongondow Propinsi Sulawesi Utara. Manado: BPTP.

Marie R, Amongo, Larona MV. 2011. Mechanizing Philippine Agriculturefor Food Sufficiency. Di dalam: Mekanisasi Petanian Berkelanjutan. Prosiding Pertemuan UNAPCAEM dan FAO. Bangkok, 8-9 Desember 2011. Bangkok: FAO. hlm 1-21.

Monke EA, Pearson ES 1989. The Policy Analysis Matrix of Agricultural Development. London: Cornell University.

Nurwahidah S, Darwanto DH, Masyhuri, Waluyati LR. 2015. Efficiency and competitiveness of corn farming in Sumbawa Regency. Journal of Agriculture and Veterinary Science 2(1):39-47.
Rehman T, Khan MU, Tayyab M. 2016. Current status and overview of farm mechanization in Pakistan. Journal of CIGR 18(2):83-93.

Setiawan B, Tambunan A, Hermawan W, Desrial, Garjito. 2006. Agricultural engineering education in Indonesia. Journal of CIGR 8(1):112.

Suryana. 2014. Prospek dan Arah Pengembangan Agribisnis Jagung. Jakarta: Departemen Petanian.

Sumarno J, Harianto. Kusnadi N. 2015. Peningkatan produksi dan efisiensi usahatani jagung melalui penerapan pengelolaan tanaman terpadu (PTT) di Gorontalo. Jurnal Manajemen \& Agribisnis 12(1):79-91.

Syuaib MF. 2016. Sustainable agriculture in Indonesia: facts and challenges to keep growing in harmony with environment. Journal of CIGR 18(2):170184.

Taiwo A, Kumi F. 2015. Status of agricultural mechanization in Ghana: a case Study Of Maize producing farmers in Ejura/Sekyedumase District, Ashanti Region. International Research Journal of Engineering and Technology 2(9):3643.

Tambunan HTT. 2013. Kebijakan Industri Dalam Menyongsong ME-ASEAN 2015. Jakarta: Kadin Indonesia.

Zangeneh M, Banaeian N. 2014. Investigation of agricultural mechanization status in corn production of Iran. Journal of CIGR 16(1): 191197. 